\title{
SHELLS OF ATLANTIDAE (HETEROPODA) COLLECTED BY THE SOYO-MARU IN THE SOUTHERN WATERS OF JAPAN
}

\author{
AUTHOR(S): \\ Tokioka, Takasi
}

\section{CITATION:}

Tokioka, Takasi. SHELLS OF ATLANTIDAE (HETEROPODA) COLLECTED BY THE SOYOMARU IN THE SOUTHERN WATERS OF JAPAN. PUBLICATIONS OF THE SETO MARINE BIOLOGICAL LABORATORY 1955, 4(2-3): 237-250

\section{ISSUE DATE:}

1955-05-30

URL:

http://hdl.handle.net/2433/174524

RIGHT: 


\title{
SHELLS OF ATLANTIDAE (HETEROPODA) COLLECTED BY THE SOYOO-MARU IN THE SOUTHERN WATERS OF JAPAN ${ }^{\prime \prime}$
}

\author{
TAKASI TOKIOKA
}

Seto Marine Biological Laboratory, Sirahama

With Plates XVII-XVIII and 10 Text-figures

Far ago, I had an opportunity of examining a number of plankton samples collected by the Sôyô-Maru chiefly in the southern waters of Japan including Bays of Sagami and Suruga and a part of the eastern waters in the years 1934 and 19371939. I selected at that time shells of Atlantidae out of the material and prepared abundant figures and data about their occurrence. Here, these figures and data are arranged for publication.

At first, the following six species are easily discriminated:

$\begin{array}{ll}\text { Oxygyrus keraudreni } & \text { Atlanta lesueuri } \\ \text { Atlanta peroni } & \text { Atlanta fusca } \\ \text { Atlanta inclinata } & \text { Atlanta turriculata }\end{array}$

1. Oxygyrus keraudreni (LESUEUR), 1817

(Figs. 1-2)

Oxygyrus keraudreni-SMITH (1888): p. 6.

VAYSSIÈRE (1904): p. 56, Pl. V figs. 71-75.

TESCH (1949): p. 10 ; Figs. 1-3, 44.

Oxygyrus keraudreni + Oxygyrus rangi-TESCH $(1908):$ pp. 5 and 6.

Oxygyrus rangi-TESCH (1906): p. 49 ; PI. VII figs. 2-4, 6B.

\begin{tabular}{c|c|c|c|c}
\hline $\begin{array}{c}\text { Long } \\
\text { diameter }\end{array}$ & $\begin{array}{c}\text { Whorl } \\
\text { formula }\end{array}$ & $\begin{array}{c}\text { Number of } \\
\text { whorls }\end{array}$ & $\begin{array}{c}\text { Aperture } \\
\text { width: } \\
\text { height }\end{array}$ & $\begin{array}{c}\text { Height of } \\
\text { keel }\end{array}$ \\
\hline $1.5 \mathrm{~mm}$ & & & & $640 \mu$ \\
1.5 & $1: 0.25:-$ & 2 & $1: 1.3$ & 690 \\
1.7 & $1: 0.24:-$ & 2 & $1: 1.3$ & 740 \\
\hline
\end{tabular}

1) Contributions from the Seto Marine Biological Laboratory, No. 257.

Publ. Seto Mar. Biol, Lab., IV (2-3), 1955, (Article 20) 

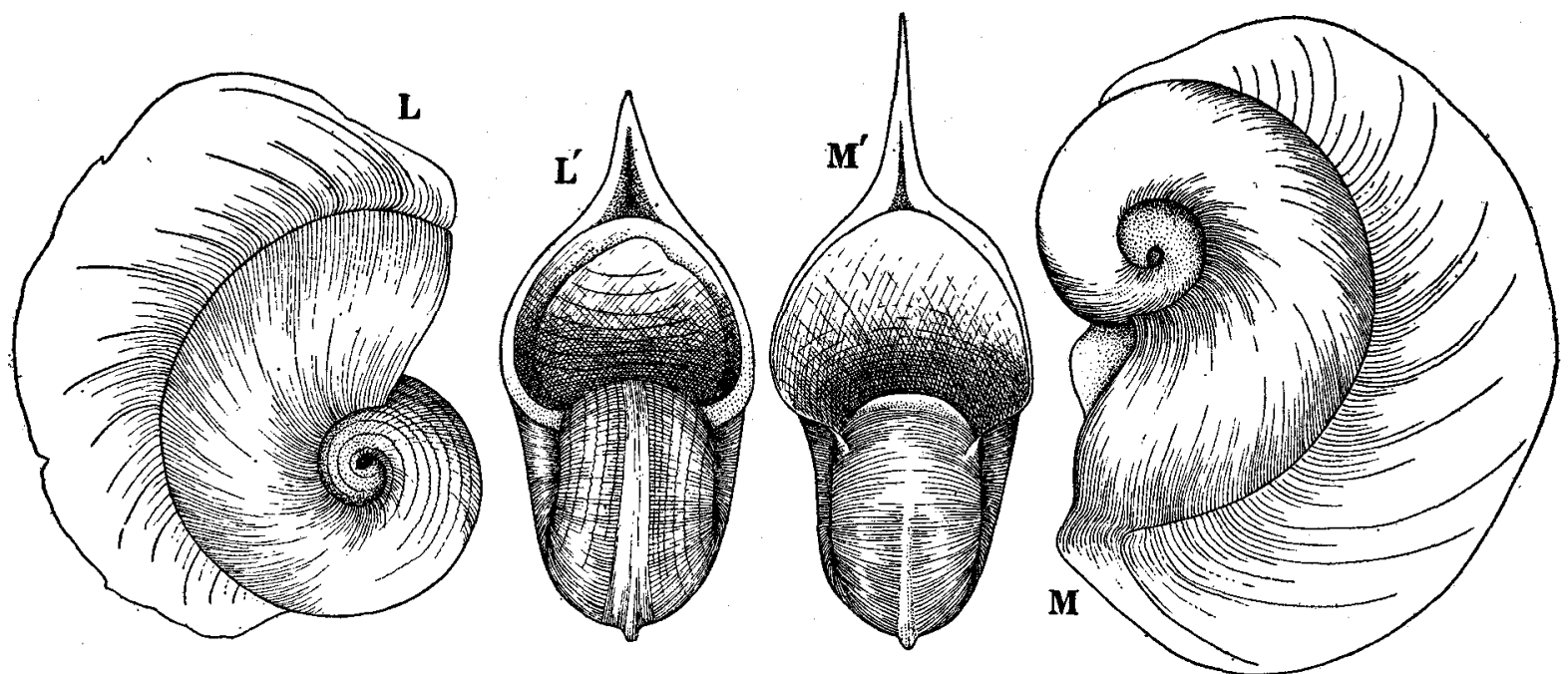

Fig. 1. Oxygyrus keraudreni (LESUEUR). $\times 28$.

$\mathrm{L}-$ Specimen with $1.5 \mathrm{~mm}$ long diameter, with striations. $\mathrm{L}^{\prime}-$ Front of the same specimen. $\mathrm{M}-$ Specimen with $1.7 \mathrm{~mm}$ long diameter, without striations. $\mathrm{M}^{\prime}-$ Front of the same specimen.

$1.5 \mathrm{~mm}$ individuals (Fig. $1 \mathrm{~L}$ and Fig. 2) are provided with distinct transverse undulating striations on the penultimatewhorl and the first $1 / 4$ of the body-whorl, while the $1.7 \mathrm{~mm}$ individual is devoid of this sculpture. Umbilicus small but very distinct. A $1.5 \mathrm{~mm}$ individual carries two spermatophores on one side of the shell, they are respectively $640 \mu$ and $710 \mu$ in length, ca. $210 \mu$ in width and yellowish in colour.

Occurrence: 1938 -St. 5 (2 individuals), St. 98 (2), St. 103 (2) ; 1939--St. 10 (1).

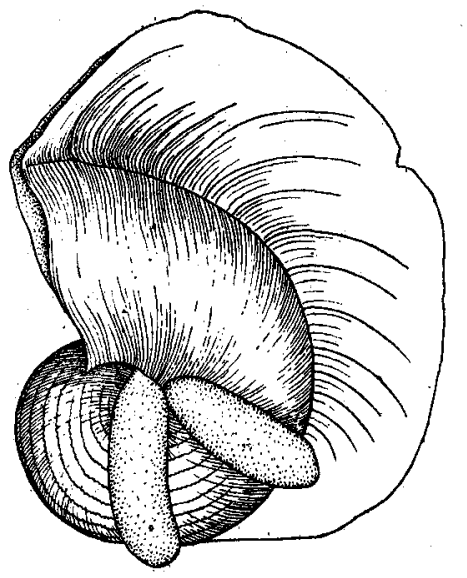

Fig. 2. Oxygyrus keraudreni (LESUEUR). $\times 28$. Specimen with $1.5 \mathrm{~mm}$ long diameter, with two spermatophores.

\section{Atlanta peroni Lesueur, 1817}

(Fig. 3)

\begin{tabular}{c|c|c|c|c}
\hline $\begin{array}{c}\text { Long } \\
\text { diameter }\end{array}$ & $\begin{array}{c}\text { Whorl } \\
\text { formula }\end{array}$ & $\begin{array}{c}\text { Number of } \\
\text { whorls }\end{array}$ & $\begin{array}{c}\text { Number of } \\
\text { whorls } \\
\text { on the } \\
\text { under-side }\end{array}$ & $\begin{array}{c}\text { Aperture } \\
\text { width: } \\
\text { height }\end{array}$ \\
\hline $\begin{array}{l}1.3 \mathrm{~mm} \\
3.2\end{array}$ & $\begin{array}{c}1: 0.34: 0.19 \\
1: 0.31: 0.11\end{array}$ & $\begin{array}{l}43 / 4 \\
5\end{array}$ & 3 & $1: 0.61$ \\
\hline
\end{tabular}


The keel is not inserted in the $1.3 \mathrm{~mm}$ individual, but it encircles $1 / 4$ of the penultimate-whorl in the $3.2 \mathrm{~mm}$ individual. Minute umbilicus observed in the $3.2 \mathrm{~mm}$ individual. Shell translucent may be whitish in some small-medium sized individuals; the base of the keel brownish in some specimens. The middle part of the inner lip brownish in the $3.2 \mathrm{~mm}$ specimen. The spire of the $1.3 \mathrm{~mm}$ individual is reddish brown in colour and striped with purplish longitudinal colour bands as shown in Fig. 3.

Occurrence: 1938-St. 95 (2); 1939-St. 21 (2), St. 84 (4).

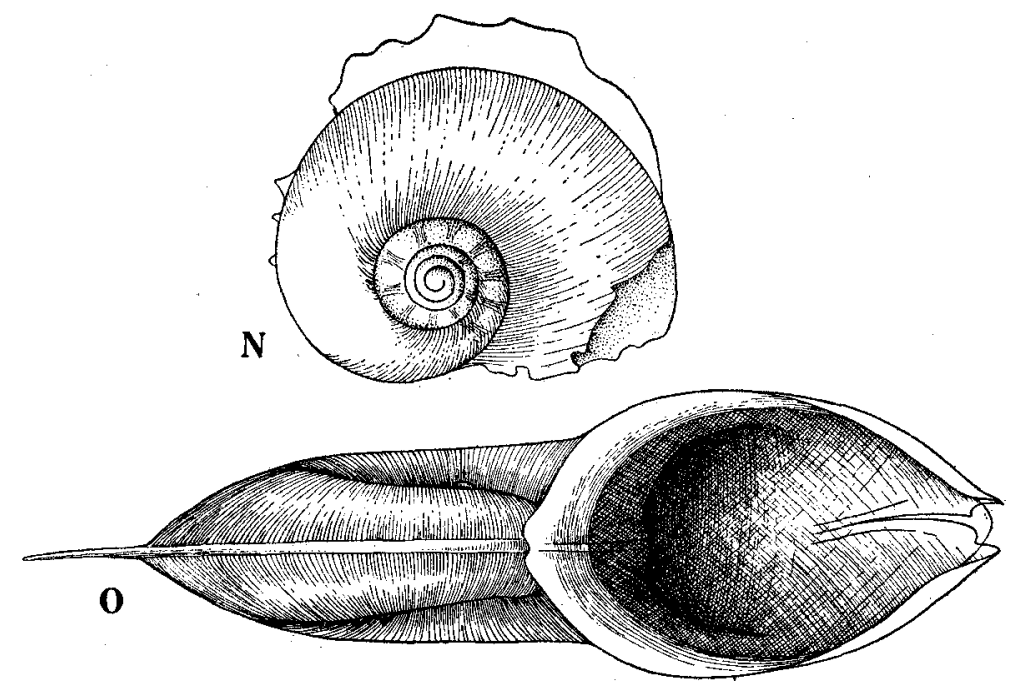

Fig. 3. Atlanta peroni LesueUr. N-Specimen with $1.3 \mathrm{~mm}$ long diameter, $\times 30$. $\mathrm{O}-$ Front of the specimen with $3.2 \mathrm{~mm}$ long diameter, $\times 28$.

3. Atlanta inclinata Souleyet, 1852

\begin{tabular}{c|c|c|c|c}
\hline \hline $\begin{array}{c}\text { Long } \\
\text { diameter }\end{array}$ & $\begin{array}{c}\text { Whorl } \\
\text { formula }\end{array}$ & $\begin{array}{c}\text { Number of } \\
\text { whorls }\end{array}$ & $\begin{array}{c}\text { Aperture } \\
\text { width: } \\
\text { height }\end{array}$ & Apical angle \\
\hline $1.8 \mathrm{~mm}$ & $1: 0.32:-$ & 6 & $1: 0.73$ & $86^{\circ}$ \\
2.1 & $1: 0.32: 0.24$ & $61 / 2$ & $1: 0.77$ & \\
5.0 & & & \\
\hline
\end{tabular}

The keel is not yet inserted in the $2.1 \mathrm{~mm}$ individual, while it encircles nearly $1 / 4$ of the penultimate-whorl in the $1.8 \mathrm{~mm}$ individual. It is rather high in the $1.8 \mathrm{~mm}$ individual, about $380 \mu$ in height. Spire strongly inclined and yellowish brown in colour. The middle part of the inner lip and the inner side of the body-whorl near the aperture are purplish in colour.

Occurrence: 1934-St. 11 (2), 1937-St. 78 (1), 1939--St. 21 (15), 


\section{Atlanta lesueuri Souleyet, 1852}

(Fig. 4)

\begin{tabular}{c|c|c|c|c}
\hline $\begin{array}{c}\text { Long } \\
\text { diameter }\end{array}$ & $\begin{array}{c}\text { Whorl } \\
\text { formula }\end{array}$ & $\begin{array}{c}\text { Number of } \\
\text { whorls }\end{array}$ & $\begin{array}{c}\text { Number of } \\
\text { whorls } \\
\text { on the } \\
\text { under-side }\end{array}$ & $\begin{array}{c}\text { Aperture } \\
\text { width: } \\
\text { height }\end{array}$ \\
\hline $1.4 \mathrm{~mm}$ & $1: 0.19: 0.10$ & $3 / / 4$ & & \\
1.9 & $1: 0.22: 0.09$ & $3 \frac{1}{1 / 2}$ & $2 / 4$ & $1: 0.66$ \\
2.1 & $1: 0.17: 0.09$ & $3 / / 4$ & 2 & $1: 0.63$ \\
2.2 & $1: 0.16: 0.07$ & $3 \mathrm{~J} / 4$ & 2 & $1: 0.62$ \\
2.4 & $1: 0.17: 0.08$ & $3 / / 4$ & 2 & $1: 0.61$ \\
2.7 & $1: 0.18: 0.07$ & $3 / 4$ & 2 & $1: 0.72$ \\
\hline
\end{tabular}

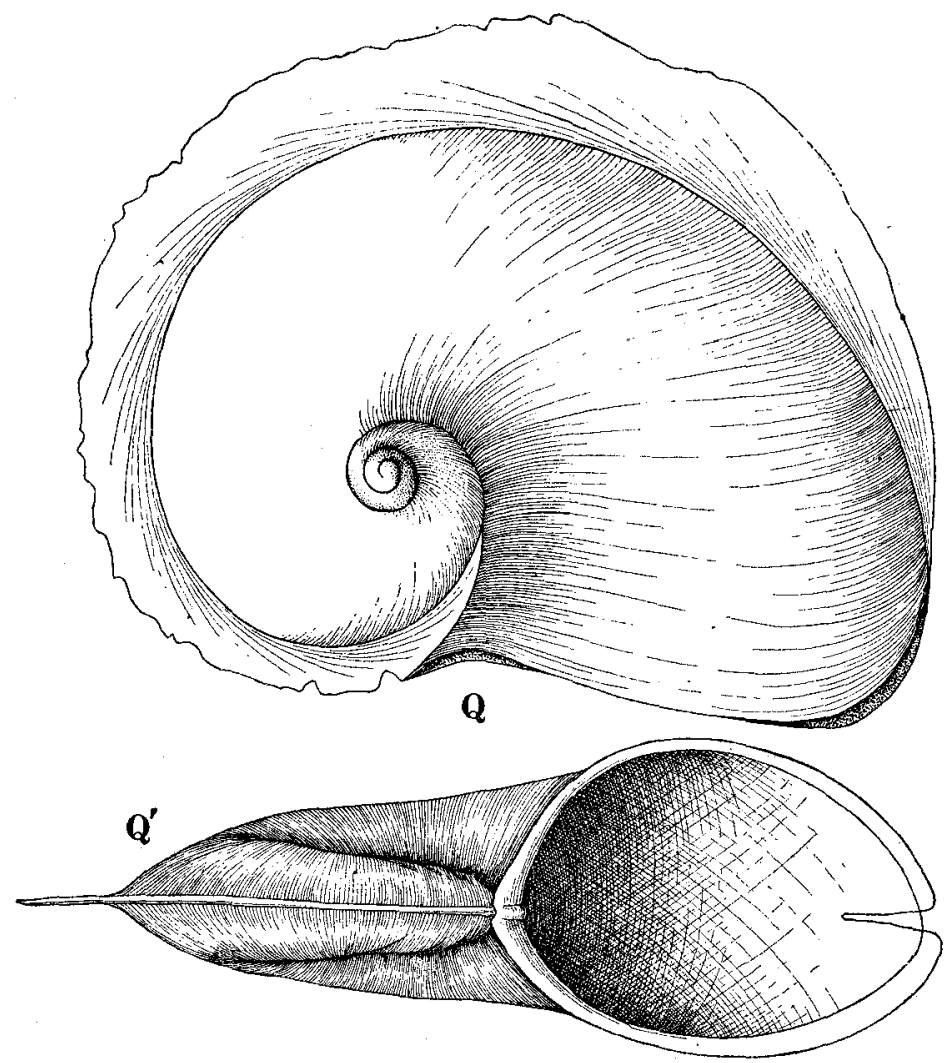

Fig. 4. Atlanta lesueuri SoUleyet. $\times 30$, Q-Specimen with $2.7 \mathrm{~mm}$ long diameter. $Q^{\prime}-$ Front of the same specimen.

The keel is slightly inserted in $1.9-2.2 \mathrm{~mm}$ specimens and encircles nearly $1 / 4$ of the penultimate-whorl in the $2.7 \mathrm{~mm}$ individual, but it is not inserted in the $2.4 \mathrm{~mm}$ individual. The spire may rarely be inclined very slightly; it is low and usually 
scarcely visible in the front view, although 1-2 tip-whorls can be seen in some specimens. The middle part of the inner lip is usually coloured violet.

Occurrence: 1934-Sagami Bay (1); St. F2 (1), St. 6' (251); 1938-St. 5 (1), St. 9 (33), St. 77 (4), St. 95 (11), St. 98 (88), St. 103 (29) ; 1939-St. 5 (3), St. 21 (8), St. 25 (1), St. 26 (1), St. 35 (1), St. 40 (1), St. 75 (1), St. 92 (1), St. 125 (3).

\section{Atlanta fusca Sovleyet, 1852}

(Pl. XVIII, Figs. J-K)

Atlanta fusca-SMTth (1888): p. 6.

TESCH (1906): p. 60, Pl. VIII figs. 28-30.

TESCH (1908): p. 25, Pls. 3 \& 4 figs. 27-29.

TESCH (1949): p. 20, Fig. 15.

Atlanta inclinata (part)-VAYssiÈre (1904): p. 53, PI. VI fig. 91.

\begin{tabular}{c|c|c|c|c|c}
\hline \multicolumn{1}{c|}{$\begin{array}{c}\text { Wong } \\
\text { diameter }\end{array}$} & $\begin{array}{c}\text { Number of } \\
\text { formula }\end{array}$ & $\begin{array}{c}\text { Number of } \\
\text { whorls } \\
\text { on the } \\
\text { under-side }\end{array}$ & $\begin{array}{c}\text { Aperture } \\
\text { width: } \\
\text { height }\end{array}$ & Apical angle \\
\hline $\begin{array}{l}1.5 \mathrm{~mm} \\
2.5\end{array}$ & $1: 0.31: 0.18$ & $4: / 4$ & & $1: 0.95$ & $72^{\circ}$ \\
$1: 0.28: 0.14$ & $43 / 4$ & 2 & $1: 0.86$ & $63^{\circ}$ \\
\hline
\end{tabular}

The keel not inserted in the $1.5 \mathrm{~mm}$ individual, while it encircles nearly $1 / 4$ of the penultimate-whorl in the $2.5 \mathrm{~mm}$ individual; it ends very near the aperture. It is very tall, about $390 \mu$ even in the smaller specimen; the basal portion is opaque and whitish, while the marginal portion is transparent. Spire erected straightly or inclined slightly. Fine undulating transverse striations on the under-side and the lower half of the upper side of the penultimate-whorl in the larger individual, while these striations are found also on the initial $1 / 4$ of the body-whorl in the smaller one. Shell bistre to pale brownish in colour, with brownish longitudinal stripes in the larger specimen. A darkly pigmented pattern beneath the operculum; generally it consists of two oval figures arranged side by side.

Occurrence: 1934-St. 13 (1), 1938-St. 9 (1), 1939-St. 21 (1).

\section{Atlanta turriculata D'ORBIGNY, 1836}

(Fig. 5)

\begin{tabular}{c|c|c|c|c|c}
\hline $\begin{array}{c}\text { Long } \\
\text { diameter }\end{array}$ & $\begin{array}{c}\text { Whorl } \\
\text { formula }\end{array}$ & $\begin{array}{c}\text { Number of } \\
\text { whorls }\end{array}$ & $\begin{array}{c}\text { Number of } \\
\text { whorls } \\
\text { on the } \\
\text { under-side }\end{array}$ & $\begin{array}{c}\text { Aperture } \\
\text { width: } \\
\text { height }\end{array}$ & Apical angle \\
\hline $1.4 \mathrm{~mm}$ & $1: 0.26: 0.16$ & $43 / 4$ & 2 & $1: 0.84$ & $42^{\circ}$ \\
1.6 & $1: 0.25: 0.12$ & $43 / 4$ & 2 & $1: 0.84$ & $25^{\circ}$ \\
2.2 & $1: 0.27: 0.12$ & $5, / 4$ & $2 / 4$ & $1: 0.85$ & $38^{\circ}$ \\
\hline
\end{tabular}


The keel not inserted in two smaller specimens, while it encircles ca. $1 / 8$ of the penultimate-whorl in the largest one. It is tall, ca. $380 \mu$ in the $1.6 \mathrm{~mm}$ individual; its wide basal portion is opaque and whitish, while the marginal portion is always transparent. The spire tall and narrow and may be slightly inclined in some specimens, it is purplish or reddish brown in colour. The $1.4 \mathrm{~mm}$ and the $1.6 \mathrm{~mm}$

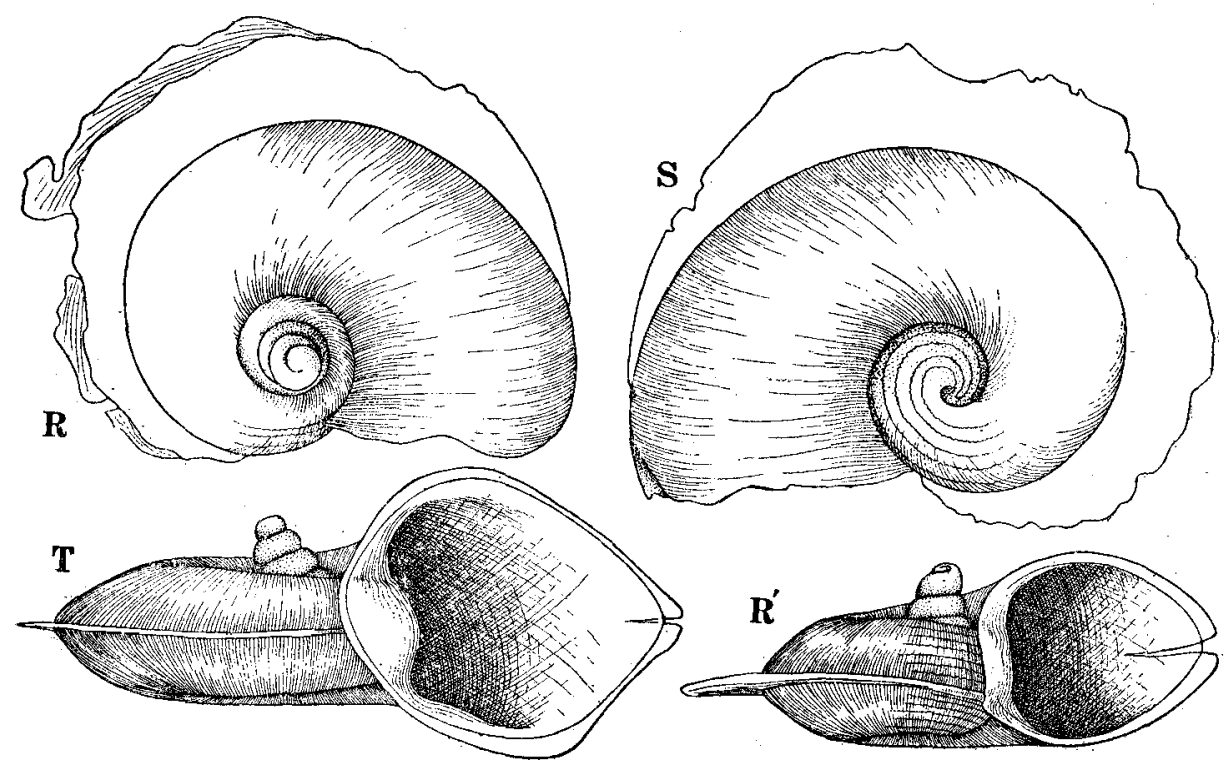

Fig. 5. Atlanta turriculata D'ORBIGNy. $\times 30$.

$\mathrm{R}$-Specimen with $1.4 \mathrm{~mm}$ long diameter. $\mathrm{R}^{\prime}-$ Front of the same specimen. $\mathrm{S}-$ Specimen with $1.6 \mathrm{~mm}$ long diameter. $\mathrm{T}-$ Front of the specimen with $2.2 \mathrm{~mm}$ long diameter.

individuals are provided with fine transverse undulating striations arranged just as in the preceding species, while the largest specimen is quite devoid of these sculptures. The middle part of the inner lip purplish in colour. The shell along the base of the keel is brownish in the $1.6 \mathrm{~mm}$ individual.

Occurrence: 1938 -St. 84 (1), St. 95 (1), St. 103 (1); 1939 -St. 5 (1), St. 18 (1).

Twenty-five representatives, remained undetermined, were measured carefully on figures drawn by using camera lucida. Then they were plotted on the graph each according to values $\mathrm{B} / \mathrm{A}$ and $\mathrm{C} / \mathrm{A}$. Specific analysis was attempted on situations of these representatives, taking the number of whorls into consideration. 

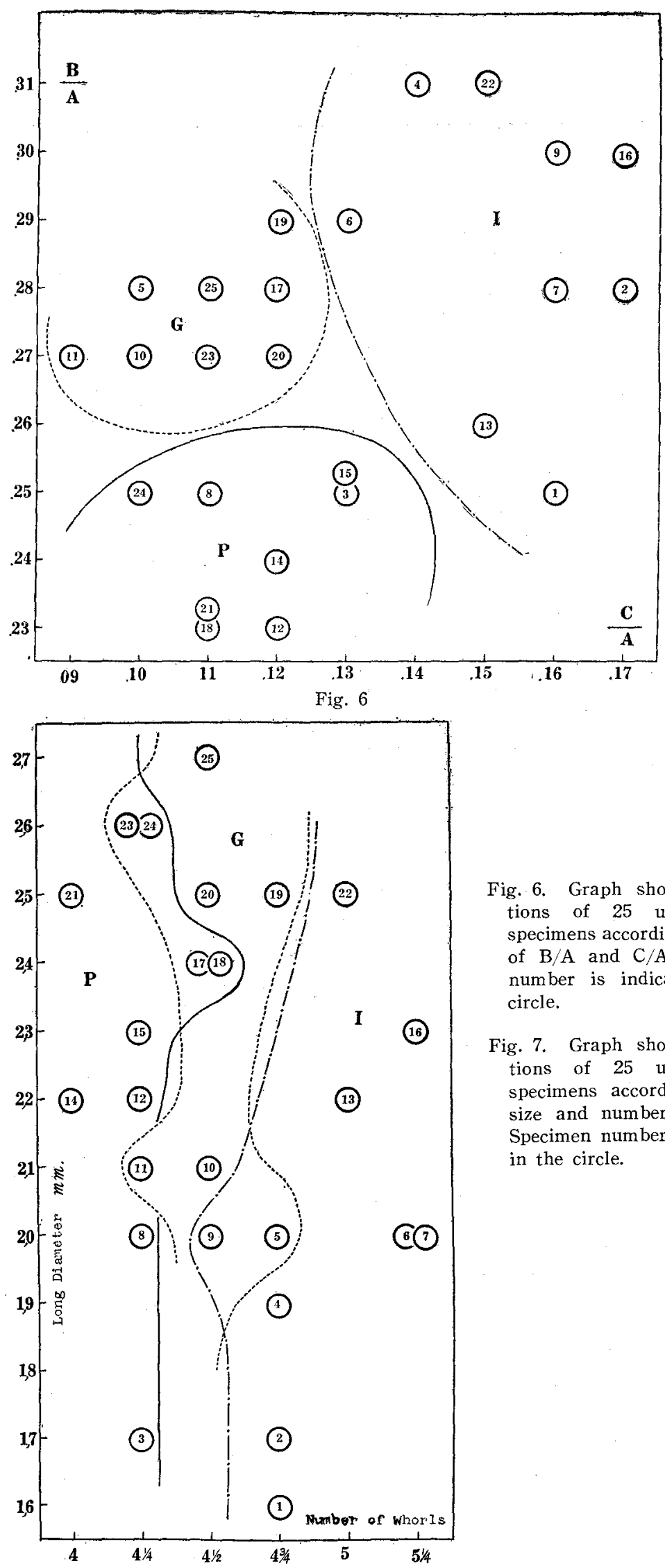

Fig. 6. Graph showing situations of 25 undetermined specimens according to values of $B / A$ and $C / A$. Specimen number is indicated in the circle.

Fig. 7. Graph showing situations of 25 undetermined specimens according to body size and number of whorls. Specimen number is indicated in the circle.

Fig. 7 


\begin{tabular}{|c|c|c|c|c|c|}
\hline $\begin{array}{l}\text { Specimen } \\
\text { number }\end{array}$ & $\begin{array}{c}\text { Long } \\
\text { diameter }\end{array}$ & $\begin{array}{l}\text { Whorl } \\
\text { formula }\end{array}$ & $\begin{array}{c}\text { Number of } \\
\text { whorls }\end{array}$ & $\begin{array}{c}\text { Number of } \\
\text { whorls } \\
\text { on the } \\
\text { under-side }\end{array}$ & Keel \\
\hline 1 & $1.6 \mathrm{~mm}$ & $1: 0.25: 0.16$ & $43 / 4$ & 2 & not inserted. \\
\hline 2 & 1.7 & $1: 0.28: 0.17$ & $43 / 4$ & 2 & $"$ \\
\hline 3 & 1.7 & $1: 0.25: 0.13$ & $4, / 4$ & 2 & $"$ \\
\hline 4 & 1.9 & $1: 0.31: 0.14$ & $43 / 4$ & 3 & $"$ \\
\hline 5 & 2.0 & $1: 0.28: 0.10$ & $43 / 4$ & $21 / 2$ & inserted very slightly. \\
\hline 6 & 2.0 & $1: 0.29: 0.13$ & $51 / 4$ & $23 / 4$ & $\left\{\begin{array}{l}\text { encircles } 1 / 4 \text { of the penul- } \\
\text { timate-whorl, }\end{array}\right.$ \\
\hline 7 & 2.0 & $1: 0.28: 0.16$ & $51 / 4$ & $21 / 4$ & not inserted. \\
\hline 8 & 2.0 & $1: 0.25: 0.11$ & $41 / 4$ & $2 / 4$ & $"$ \\
\hline 9 & 2.0 & $1: 0.30: 0.16$ & $41 / 2$ & $21 / 4$ & " \\
\hline 10 & 2.1 & $1: 0.27: 0.10$ & $4^{1 / 2}$ & $21 / 2$ & $"$ \\
\hline 11 & 2.1 & $1: 0.27: 0.09$ & $41 / 4$ & $21 / 2$ & $"$ \\
\hline 12 & 2.2 & $1: 0.23: 0.12$ & $4 / 4$ & 2 & $"$ \\
\hline 13 & 2.2 & $1: 0.26: 0.15$ & 5 & $21 / 4$ & $"$ \\
\hline 14 & 2.2 & $1: 0.24: 0.12$ & 4 & 2 & $"$, \\
\hline 15 & 2.3 & $1: 0.25: 0.13$ & $41 / 4$ & 2 & $\left\{\begin{array}{l}\text { encircles } \frac{x}{4} \text { of the penul- } \\
\text { timate-whorl. }\end{array}\right.$ \\
\hline 16 & 2.3 & $1: 0.30: 0.17$ & $51 / 4$ & $2 / 4$ & not inserted. \\
\hline 17 & 2.4 & $1: 0.28: 0.12$ & $41 / 2$ & $3 / 4$ & inserted very slightly. \\
\hline 18 & 2.4 & $1: 0.23: 0.11$ & $41 / 2$ & 2 & not inserted. \\
\hline 19 & 2.5 & $1: 0.29: 0.12$ & $43 / 4$ & $2 / 4$ & $"$ \\
\hline 20 & 2.5 & $1: 0.27: 0.12$ & $4 / 2$ & $23 / 4$ & , . \\
\hline 21 & 2.5 & $1: 0.23: 0.11$ & 4 & 2 & $\left\{\begin{array}{l}\text { encircles } 1 / 8 \text { of the penul- } \\
\text { timate-whorl. }\end{array}\right.$ \\
\hline 22 & 2.5 & $1: 0.31: 0.15$ & 5 & $2, / 4$ & not inserted. \\
\hline 23 & 2.6 & $1: 0.27: 0.11$ & $41 / 4$ & $2 / 4$ & $"$ \\
\hline 24 & 2.6 & $1: 0.25: 0.10$ & $4, / 4$ & $21 / 2$ & inserted very slightly. \\
\hline 25 & 2.7 & $1: 0.28: 0.11$ & $4 \frac{1}{2}$ & & not inserted. \\
\hline
\end{tabular}

At Figures 6 and 7 , three groups may be readily distinguishable from one another, of which Group G consists of specimens Nos. 5, 10, 11, 17, 19, 20, 23 and 25, Group P includes specimens Nos. 3, 8, 12, 14, 15, 18, 21 and 24 and Group I is constituted with specimens Nos. $1,2,4,6,7,9,13,16$ and 22 . The Group $I$ is characterized by high values of $\mathrm{B} / \mathrm{A}$ and $\mathrm{C} / \mathrm{A}$ and the large number of whorls, the Group $G$ by relatively high value of $B / A$ and low $C / A$ and the Group $P$ by low values of both $\mathrm{B} / \mathrm{A}$ and $\mathrm{C} / \mathrm{A}$. The measurements on figures of type specimens or typical specimens of several species drawn by $\mathrm{TESCH}$ by using camera lucida show the following numerical characteristics:--

\begin{tabular}{|c|c|c|c|}
\hline \multicolumn{2}{|c|}{ Atlanta gaudichaudi } \\
\hline Long diameter & Whorl formula & Number of whorls & Source \\
\hline $2.8 \mathrm{~mm}$ & $1: 0.31: 0.11$ & $4 \frac{1}{4}$ & 1906 \\
2.8 & $1: 0.28: 0.10$ & $43 / 4$ & 1908 \\
3.0 & $1: 0.29: 0.09$ & $4 \frac{1}{2}$ & 1949 \\
\hline
\end{tabular}




\begin{tabular}{|c|c|c|c|}
\hline \multicolumn{4}{|c|}{ Allanta inflata } \\
\hline 1.4 & $1: 0.33: 0.22$ & $41 / 2$ & 1906 \\
\hline 1.5 & $1: 0.28: 0.15$ & $51 / 2$ & 1908 \\
\hline 1.7 & $1: 0.33: 0.16$ & $43 / 4$ & 1949 \\
\hline 1.8 & $1: 0.30: 0.16$ & 6 & 1908 \\
\hline \multicolumn{4}{|c|}{ (Atlanta depressa) } \\
\hline 1.7 & $1: 0.32: 0.18$ & 5 & 1908 \\
\hline \multicolumn{4}{|c|}{ (Atlanta rosea) } \\
\hline 1.5 & $1: 0.28: 0.17$ & 5 & 1906 \\
\hline \multicolumn{4}{|c|}{ Atlanta helicinoides } \\
\hline 1.5 & $1: 0.37: 0.22$ & $41 / 2$ & 1908 \\
\hline 1.8 & $1: 0.35: 0.19$ & 6 & 1949 \\
\hline
\end{tabular}

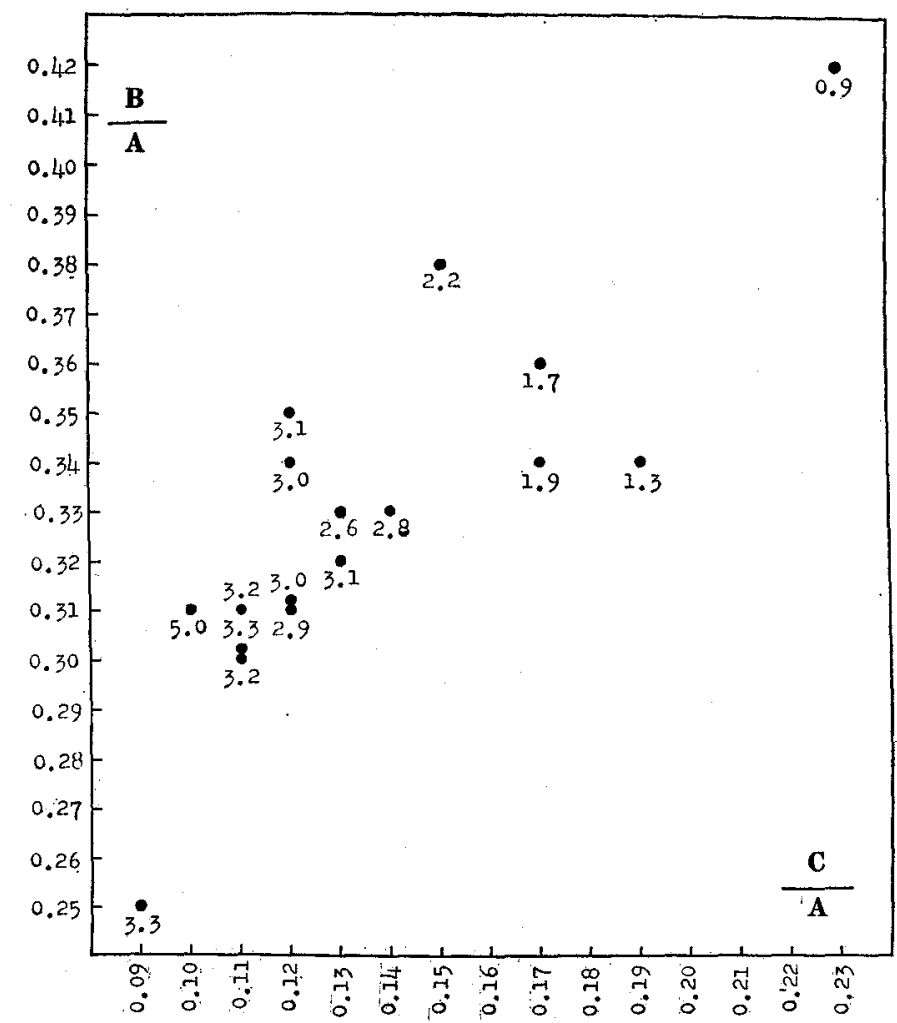

Fig. 8. Atlanta peroni LESUEUR.

Graph showing the relation between the body size and values of $\mathrm{B} / \mathrm{A}$ and $\mathrm{C} / \mathrm{A}$. Numerals indicate long diameters of specimens in $\mathrm{mm}$. 
Comparing the numerical data of three groups carefully with the table given above, it is easily understood that the Group I represents Atlanta inflata and the Group G Atlanta gaudichaudi. Here, the_Group P remains undetermined.

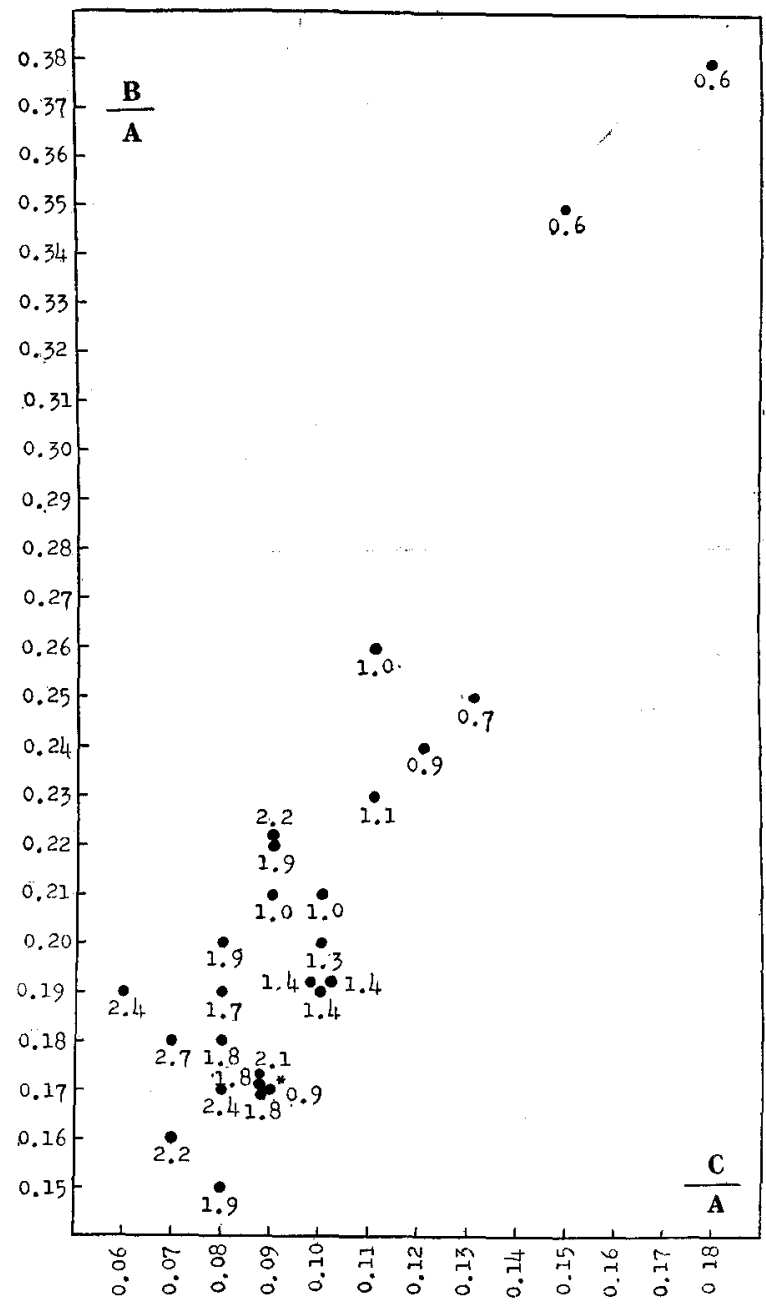

Fig. 9. Allanta lesueuri Souleyet.

Graph showing the relation between the body size and values of $\mathrm{B} / \mathrm{A}$ and $\mathrm{C} / \mathrm{A}$. Numerals indicate long diameters of specimens in $\mathrm{mm}$.

Generally speaking, the number of whorls increases with the size of the shell. Thus, it is impossible that the Group $\mathrm{P}$ represents the older stages of At. inflata, because in spite of the fact that many specimens in the Group $\mathrm{P}$ are much larger than some of At. inflata, they are provided with less whorls. Then arises the question whether the Group $\mathrm{P}$ represents a phase of the variation in Atlanta gaudichaudi or 
not. To offer a ground on which the present question may be discussed, the numerical data of At. peroni and At. lesueuri, both commonly and numerously occurring species in the western Pacific, are figured in graphs showing the relation between the body size and values $\mathrm{B} / \mathrm{A}$ and $\mathrm{C} / \mathrm{A}$. At Figures 8 and 9 , it is conceivable that values $\mathrm{B} / \mathrm{A}$ and $\mathrm{C} / \mathrm{A}$ become smaller according to the growth of the shell. The distribution of specimens of the Groups $P$ and $G$ in Fig. 6 does not seem to be arranged in the order of the body size, but rather it seems quite irregular. Thus, the Group $P$ can not be considered as the group embracing older stages of At. gaudichaudi in spite of the lower value of $\mathrm{B} / \mathrm{A}$ in the Group $\mathrm{P}$. Number of whorls in the Group $\mathrm{P}$ slightly fewer than in At. gaudichaudi seems to guarantee the present consideration. There are two possible ideas about the Group $\mathrm{P}$, one is that the Group $\mathrm{P}$ represents a new species and the other means the existence of the range of variation in values $\mathrm{B} / \mathrm{A}$ and $\mathrm{C} / \mathrm{A}$ and the number of whorls in At. gaudichaudi much wider than hitherto be considered. At present, I propose to treat the Group $\mathrm{P}$ as a new species for convenience' sake of recording and to name it Atlanta pacifica.

\section{Atlanta gaudichaudi SOULEYET, 1852}

(Pl. XVIII, Figs. H-I ; Text-fig. 10)

Nine specimens $(2.0-2.7 \mathrm{~mm}$ in long diameter) were measured; $\mathrm{B} / \mathrm{A}$ is $0.27-0.29$ (0.28 on average) and $\mathrm{C} / \mathrm{A}$ is $0.09-0.13$ ( 0.11 on average); number of whorls $4^{1 / 4}-5^{1 / 4}$ (ca. $4^{1 / 2}$ on average) and number of whorls on the under-side is $2^{1 / 4}-3 / 4$ (mean number ca. 2/2), and the height/width of the aperture is $0.52-0.66$ (0.59 on average). The keel is usually not inserted, although it is slightly inserted or encircles ca. $1 / 4$ of the penultimate-whorl in three of the examined specimens. It may be rather tall in some specimens, for instance $470 \mu$ in height in a $2.7 \mathrm{~mm}$ specimen (not inserted); the basal part is generally thickened considerably. Spire purplish in colour and low, merely, the tip or the neighbourhood of the tip is visible in the front view of the shell; in some individuals it is quite concealed by the body-whorl. Shell translucent and faintly purplish, may be whitish in rare cases. Brownish tint along the keel base and the suture in some specimens. Small but deep umbilicus may be found in some specimens.

Occurrence: 1934-Sagami Bay (1); 1938-St. 2 (1), St. 9 (8), St. 13 (93), St. 98 (2); 1939 - St. 70 (2). 

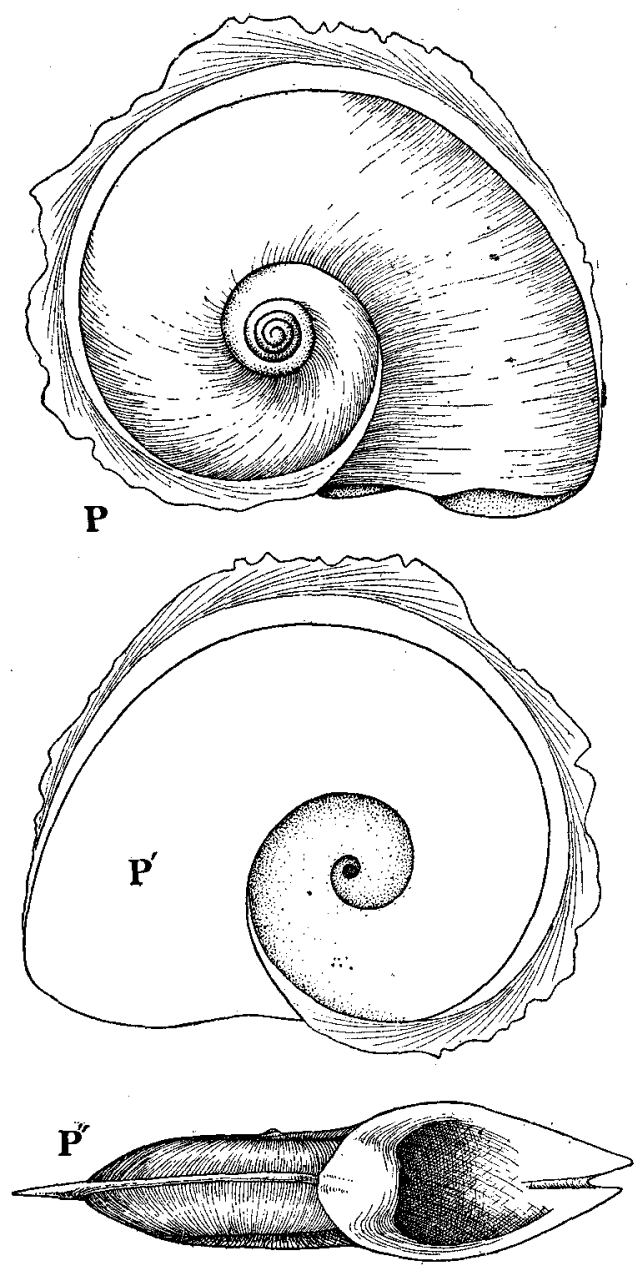

Fig. 10. Atlanta gaudichaudi SOULEyET with inserted keel, $\times 28$. $\mathrm{P}$-Specimen with $2.0 \mathrm{~mm}$ long diameter. $\mathrm{P}^{\prime}$-Under-side of the same specimen. $\mathrm{P}^{\prime \prime}-$ Front of the same specimen.

\section{Atlanta inflata Souleyet, 1852}

(Pl. XVII, Figs. A-C)

Eight specimens (1.6-2.5 $\mathrm{mm}$ in long diameter) were measured; $\mathrm{B} / \mathrm{A}$ is $0.25-0.31$ ( 0.29 on average) and $\mathrm{C} / \mathrm{A}$ is $0.14-0.17$ ( 0.16 on average); number of whorls $4 \frac{1}{2}-$ $5 \frac{1}{4}$ (mean number ca. 5) and number of whorls on the under-side is 2-3 (mean number ca. $2 / 4)$, and the height/width of the aperture is $0.60-0.89(0.74$ on average). The keel is never inserted; it is tall in some specimens, for instance $580 \mu$ in the $2.3 \mathrm{~mm}$ specimen. The basal part of the keel is opaque and whitish in colour, while 
the marginal part is translucent. Spire purplish or purplish brown in colour and tall and wide, with the apical angle $84^{\circ}-125^{\circ}, 107^{\circ}$ on average. It is erected straightly or inclined slightly, and protruded prominently from the level of the upper edge of the body-whorl and easily observable in the front view. Faint and fine transverse striations on the under-side of the spire of the $1.6 \mathrm{~mm}$ individual. Shell whitish or purplish in colour, the neighbourhood of the aperture is translucent; the keel base and sutures are brownish in some specimens. The middle part of the inner lip is purplish.

Occurrence: 1934-St. 11 (1); 1938-St. 9 (6), St. 84 (3), St. 95 (2), St. 98 (6), St. 103 (5) ; 1939--St. 21 (4), St. 30 (1), St. 125 (1).

\section{Atlanta pacifica n. sp.}

(Pl. XVII, Figs, D-G)

Eight specimens $(1.7 \mathrm{~mm}-2.6 \mathrm{~mm}$ in long diameter $)$ were measured; $\mathrm{B} / \mathrm{A}$ is $0.23-0.25$ ( 0.24 on average) and $\mathrm{C} / \mathrm{A}$ is $0.10-0.13$ (ca. 0.12 on average); number of whorls $4-4^{1 / 2}$ (mean number $4 / 4$ ) and number of whorls on the under-side is $2-2^{1 / 2}$ (mean number between 2 and $2 \frac{1}{4}$ ), and the height/width of the aperture is $0.54-0.78$ (mean value 0.66). The keel may be slightly inserted in some specimens, for instance it encircles $1 / 4$ of the penultimate-whorl in the $2.3 \mathrm{~mm}$ individual and $1 / 8$ in the $2.5 \mathrm{~mm}$ individual. It is usually low, although it reaches to $440 \mu$ in height in a $2.2 \mathrm{~mm}$ specimen. Spire purplish in colour, erected straightly or slightly inclined; it is more prominent than in At. gaudichaudi, but less remarkable than in At. inflata; the apical angle is $103^{\circ}-116^{\circ}$ (mean angle 108 ${ }^{\circ}$. Shell whitish in some specimens, the base of the keel faintly brownish in some specimens. Small umbilicus may be found on some individuals.

Remarks: The present new species resembles most closely At. gaudichaudi. The differences between these two species are already discussed fully (pp. 242-247).

Occurrence: 1934 -St. 11 (25), St. 13 (72); 1937-St. 13 (82); 1938--St. 13 (7), St. 60 (2), St. 84 (1), St. 103 (2); 1939-St. 21 (20), St. 80 (3).

There are besides four specimens; 1934-St. 13 (1), 1939-St. 77 (2) and ? 1. They are, however, mutilated too much to be identified strictly.

Lastly I wish to express here my hearty thanks to Prof. H. Arkawa who gave me kindly the chance to examine the present material at the Central Fisheries Experimental Station in Tokyo in 1939. 


\section{EXPLANATION OF PLATES XVII-XVIII}

Plate XVII

Figs. A-C. Atlanta inflata Souleyet. $\times 30$.

A … Specimen with $2.3 \mathrm{~mm}$ long diameter.

$\mathrm{A}^{\prime} \cdots$ Front of the same specimen.

B $\cdots$ Under-side of the specimen with $2.2 \mathrm{~mm}$ long diameter.

C $\cdots$ Front of the specimen with $2.5 \mathrm{~mm}$ long diameter.

Figs. D-G. Atlanta pacifica n. sp. $\times 30$.

D $\cdots$ Specimen with $2.3 \mathrm{~mm}$ long diameter.

$\mathrm{D}^{\prime} \cdots$ Under-side of the same specimen.

$\mathrm{D}^{\prime \prime} \ldots$ Front of the same specimen.

E ... Specimen with $2.2 \mathrm{~mm}$ long diameter.

$\mathrm{F}$... Under-side of the shell with $2.2 \mathrm{~mm}$ long diameter.

$F^{\prime} \cdots$ Front of the same specimen.

G $\cdots$ Front of the shell with $2.6 \mathrm{~mm}$ long diameter.

\section{Plate XVIII}

Figs. H-I. Atlanta gaudichaudi Souleyet.

$\mathrm{H} \cdots$ Specimen with $2.7 \mathrm{~mm}$ long diameter, $\times 30$.

$\mathrm{H}^{\prime} \cdots$ Front of the same specimen, $\times 30$.

I $\cdots$ Specimen with $2.1 \mathrm{~mm}$ long diameter, $\times 28$.

$\mathrm{I}^{\prime}$... Under-side of the same specimen, $\times 28$.

$I^{\prime \prime} \cdots$ Front of the same specimen, $\times 28$.

Figs. J-K. Atlanta fusca Souleyet. $\times 30$.

$\mathrm{J}$... Specimen with $2.5 \mathrm{~mm}$ long diameter.

$\mathrm{J}^{\prime}$... Under-side of the same specimen.

$J^{\prime \prime} \cdots$ Front of the same specimen.

$\mathrm{K}$... Specimen with $1.5 \mathrm{~mm}$ long diameter.

$\mathrm{K}^{\prime} \cdots$ Front of the same specimen. 
Publ. Seto Mar. Biol. Lab., IV, 2-3 (1955)

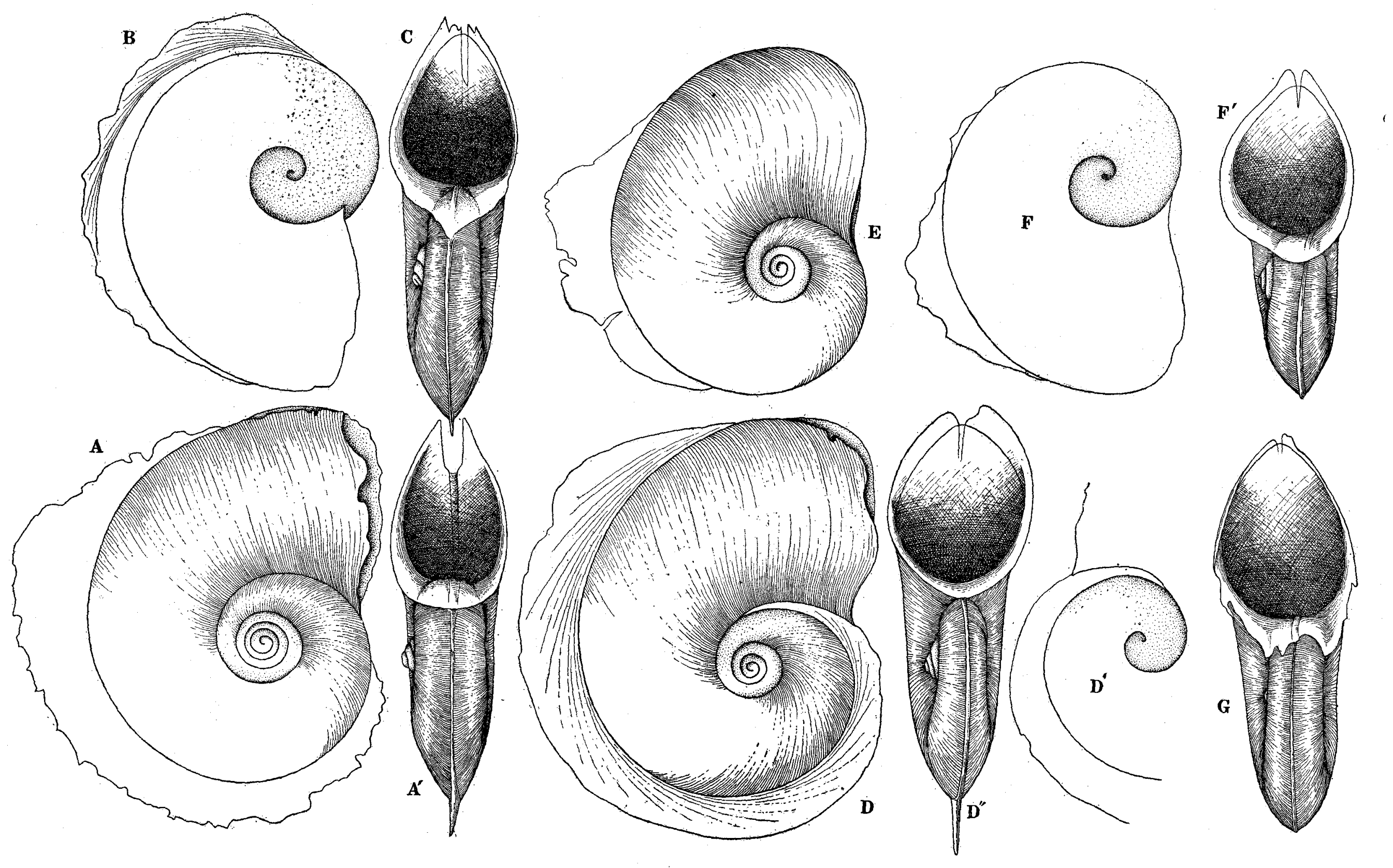

T. Tokioka; Shelis of AtLantidae Collected by the Sôyô-Maru. 

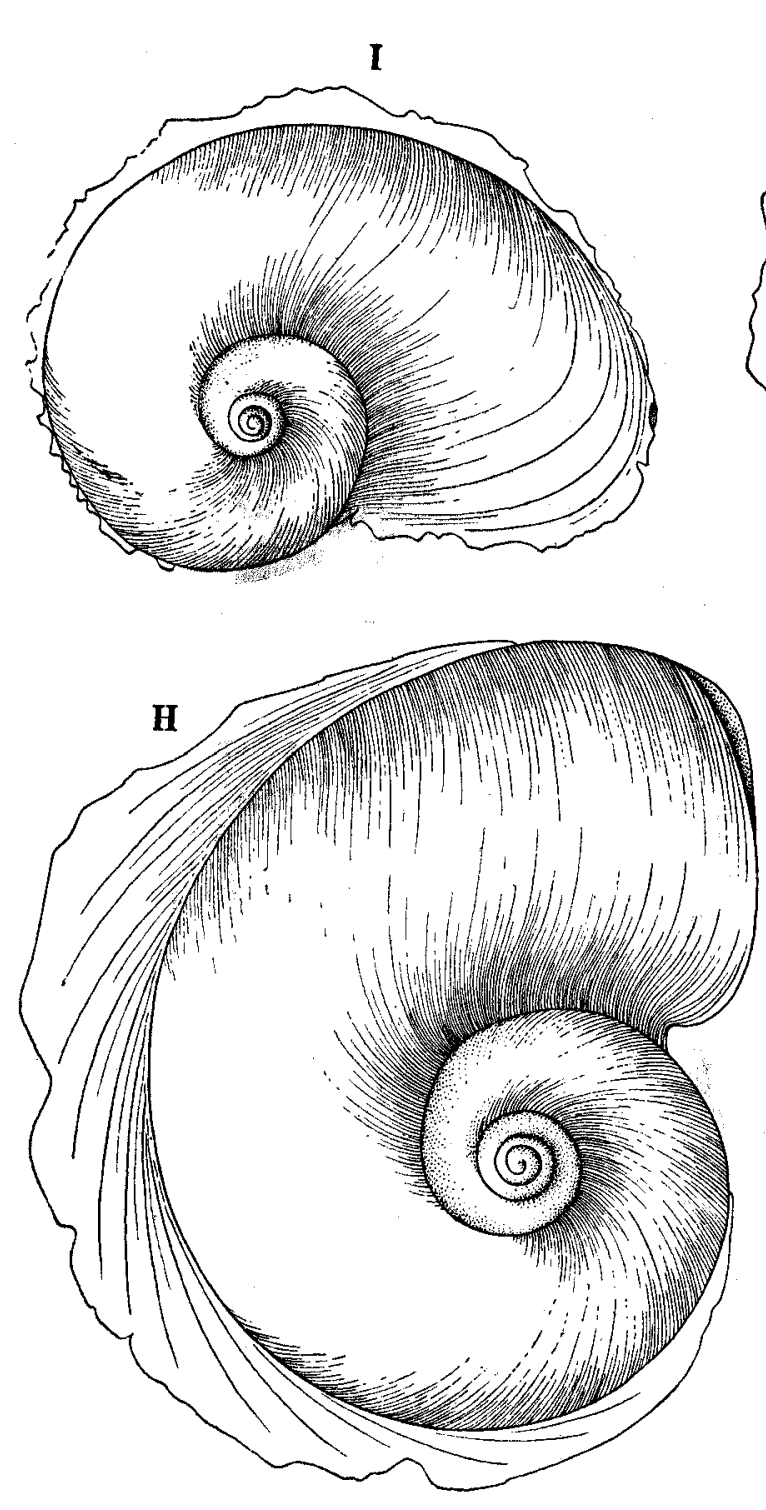
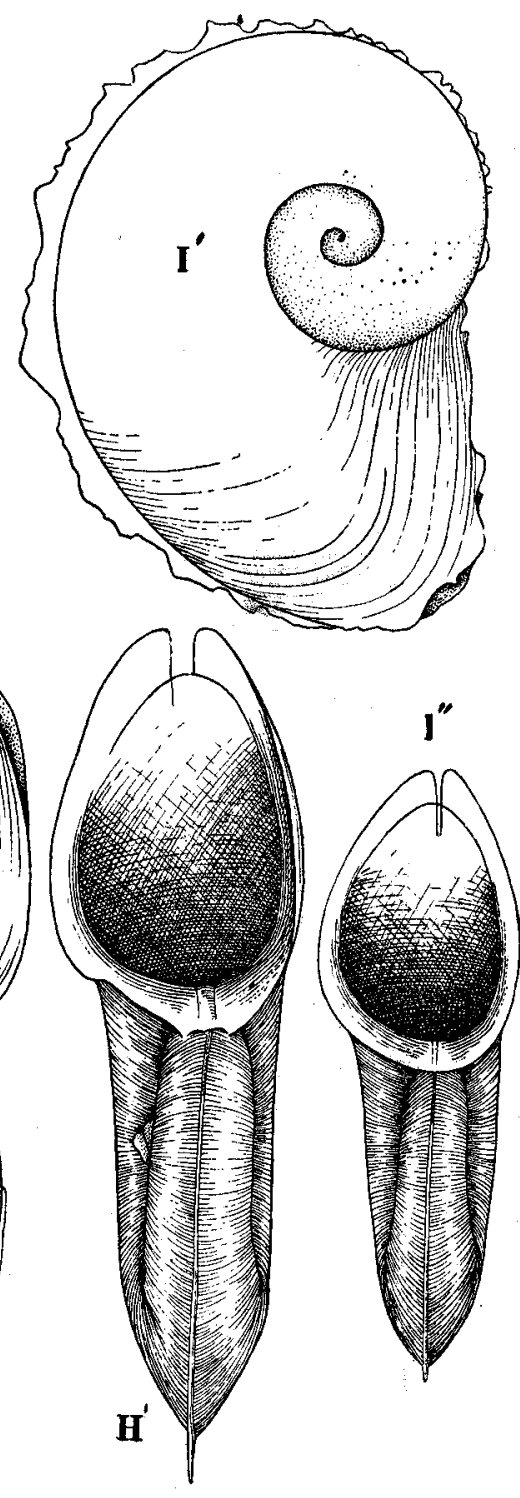
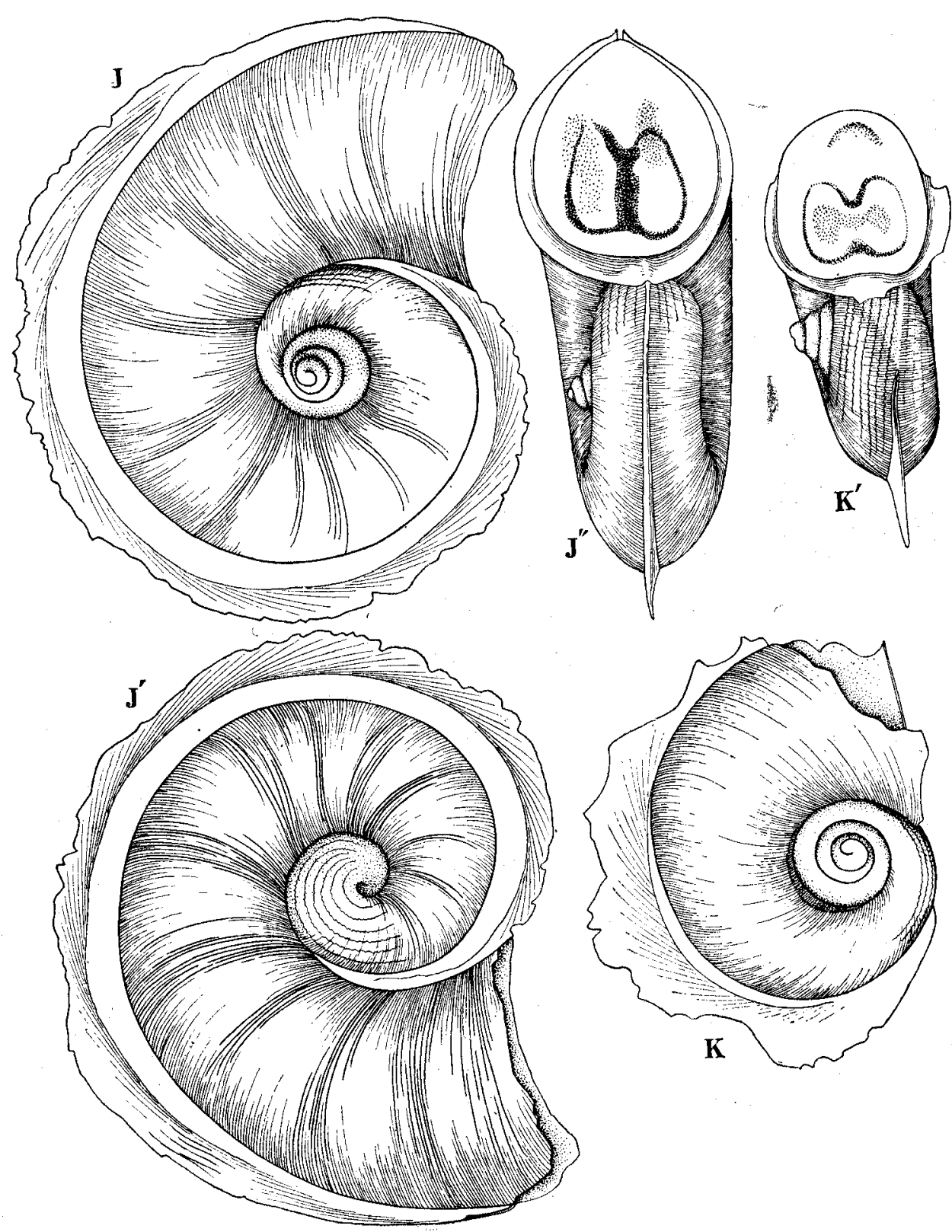

T. Tokioka: Shells of Atlantidae Collected bY The Sôyô-Maru. 